\title{
Struktur Populasi dan Performans Reproduski Ternak Babi di Kabupaten Sumba Timur
}

\section{Population Structure and Reproduction Performance of Pigs in East Sumba Regency}

\author{
A. Kaka, R. R. Dapawole dan A. U. H. Pari \\ Program Studi Peternakan Fakultas Sains dan Teknologi Universitas Kristen Wira Wacana Sumba \\ Jl. R. Soeprapto No.35 Waingapu-NTT \\ Corresponding email: alexanderkaka84@yahoo.com
}

\begin{abstract}
This study aimed to determine the population structure and reproduction performance of pigs in East Sumba Regency. The study was conducted from February to May 2017 with the research method used is a survey with direct interviews of 200 respondents. Data were analyzed by descriptive statistical approach which is depicted in the frequency table of each indicator. The measured variables were male and female population structure covering children (0-3 months), young (3-7 months), adults (>8 months). While reproductive performance includes duration of estrus, estrus cycle, litter size, wean count, mortality rate. The results showed that the population structure of pigs in the dominance of female livestock: male sequentially include children $53.39: 46.61 \%$, young $57.50: 42,50 \%$, adults $54.17: 45,83 \%$. While the reproduction performance of pigs such as estrus length 3.25 day, estrus cycle 20.45 day, liter size 9.75 tail and mortality $17.03 \%$. Thus it can be concluded that the structure of pig population is dominated by females. While the reproduction performance of pigs are classified as good category.
\end{abstract}

Key words : population structure, reproductive performance, pigs

\begin{abstract}
ABSTRAK
Penelitian ini bertujuan untuk mengetahui struktur populasi dan performans reproduksi ternak babi di Kabupaten Sumba Timur. Penelitian dilaksanakan dari bulan Februari sampai dengan Mei 2017 dengan metode penelitian yang digunakan adalah survei dengan wawancara langsung terhadap 200 responden. Data dianalisis dengan pendekatan statistik deskriptif yang digambarkan pada tabel frekuensi dari setiap indikator. Variabel yang diukur adalah struktur populasi jantan dan betina yang meliputi anak ( $0-3$ bulan), muda (3-8 bulan), dewasa ( $>8$ bulan). Performans reproduksi meliputi lama estrus, siklus estrus, litter size, jumlah sapih, angka mortalitas. Hasil penelitian menunjukkan bahwa struktur populasi ternak babi didominasi ternak betina: jantan secara berurutan meliputi anak 53.39:46.61\%, muda 57.50:42,50\%, dewasa 54.17: 45,83\%. Performans reproduksi ternak babi yakni lama estrus 3,25 hari, siklus estrus 20,45 hari, liter size 9,75 ekor serta mortalitas $17,03 \%$. Dengan demikian dapat disimpulkan bahwa struktur populasi ternak babi didominasi ternak betina. Performans reproduksi induk ternak babi tergolong dalam kategori baik.
\end{abstract}

Kata kunci: struktur populasi, performans reproduksi, babi

\section{PENDAHULUAN}

Ternak babi telah menjadi bagian dari kehidupan sosial budaya masyarakat khususnya di Kabupaten Sumba Timur Propinsi Nusa Tenggara Timur sehingga sangat potensial untuk di kembangkan sebagai penghasil daging, tabungan dan meningkatkan status sosial masyarakat serta mendukung ekonomi keluarga. Menurut Sapanca et al., (2015), ternak babi sebagai penyumbang protein yang telah diakui seluruh dunia. Sedangkan beberapa daerah di Indonesia, ternak babi dibutuhkan untuk kegiatan adat istiadat (Soewandi dan Talib 2015). Untuk daerah NTT memiliki potensi ternak babi untuk dikembangkan dengan tujuan utama sebagai tabungan yang sewaktu-waktu dapat diuangkan (Wea, 2007).

Data BPS (2019), yakni populasi ternak babi di Sumba Timur mencapai 124.699 ekor dengan peningkatan populasi pada tahun 20182019 hanya mencapai 3,16\%. Rendahnya angka peningkatan populasi tersebut disebabkan tinggi angka mortalitas ternak yakni mencapai $39,71 \%$ (Kaka, 2017) serta ternak terserang penyakit setiap tahun sehingga mengalami kematian, pemotongan ternak untuk kebutuhan adatistiadat, mutasi ternak di luar daerah (BPS, 2014) dan rendahnya performans reproduksi ternak babi dengan beberapa indikator antara lain 
produktivitas ternak babi masih belum optimal (Geisert dan Schmitt, 2002).

Mengingat peranan ternak babi yang sangat besar bagi masyarakat maka ternak babi perlu mendapat perhatian untuk dikembangkan dimana sistem pemeliharaan yang bersifat tradisional dan sebagai usaha sampingan dengan kepemilikan berkisar antara 1-7 ekor per kepala keluarga. Hal ini terlihat penyebaran populasi ternak babi yang tidak merata dibeberapa kecamatan di Sumba Timur yakni Kecamatan Kanatang 4.167 ekor, Kota Waingapu 6.365 ekor, Kambera 12.030 ekor dan Lewa Tidahu hanya 2.783 ekor (BPS, 2019). Kondisi ini dapat mempengaruhi tingkat penghasilan dari peternak baik dari perbedaan ekonomi maupun pemenuhan gizi. Sebagai langkah dasar dapat dilakukan penelitian untuk mendapatkan infromasi tentang struktur populasi dan performans reproduksi ternak babi di Kabupaten Sumba Timur.

\section{MATERI DAN METODE}

\section{Metode Pengambilan Populasi dan Sampel}

Metode pengambilan sampel penelitian ini dilakukan dengan metode survei dengan pengamatan langsung di lapangan, di Kelurahan Kambajawa dan Kelurahan Prailiu Kabupaten Sumba Timur yang berlangsung 2 Februari 201730 April 2017. Pengambilan populasi (200 orang) dan sampel (196 ekor) dilakukan secara purposive random sampling yakni sampel yang diambil berdasarkan kriteria yang telah ditetapkan dengan menggunakan rumus slovin sebagai berikut:

$$
n=\frac{N}{1+N(e)^{2}}
$$

Ket :

$$
\begin{aligned}
& \mathrm{n} \quad \text { : Ukuran sampel } \\
& \mathrm{N} \quad \text { : Jumlah Populasi (200) } \\
& \mathrm{e}^{2} \quad \text { : Prosentase pengambilan sampel yang } \\
& \text { masih diinginkan }(1 \%)
\end{aligned}
$$

\section{Variabel}

Adapun variabel yang diteliti dalam penelitian ini adalah sebagai berikut :

1) Jumlah anak yang berumur 0-3 bulan dihitung untuk membandingkan antara anak jantan dan betina.

2) Jumlah ternak muda berumur 4-7 bulan dihitung berdasarkan perbandingan jantan dan betina
3) Jumlah ternak dewasa berumur diatas 8 bulan yaitu perbandingan ternak babi jantan maupun betina

4) Estrus dan siklus estrus (\%) yaitu jumlah induk yang estrus dan bersiklus estrus di bagi dengan total induk yang diteliti kemudian dikali dengan $100 \%$.

5) Litter size (rataan) adalah jumlah anak yang lahir per induk kemudian diambil rataan anak babi dari semua induk.

6) Angka mortalitas (\%) adalah jumlah anak babi yang mati sebelum disapih.

\section{Metode Analisis Data}

Data yang telah dikumpulkan, dikelompokkan dan ditabulasi menurut umur ternak dan jenis kelamin serta performans reproduksi ternak babi kemudian ditabulasi dan dianalisis secara deskriptif eksploratif (Sugiyono, 2013).

\section{HASIL DAN PEMBAHASAN}

\section{Karakteristik Responden}

Data penelitian tentang struktur populasi dan performans reproduksi ternak tergantung

\begin{tabular}{|c|c|c|}
\hline No. & Responden & Persentase \\
\hline \multirow{3}{*}{ A. } & Jenis Kelamin & \\
\hline & Laki-laki & $43,10 \%$ \\
\hline & Perempuan & $56,90 \%$ \\
\hline \multirow[t]{4}{*}{ B. } & Umur : & \\
\hline & a) $<40$ tahun & $20,70 \%$ \\
\hline & b) 41-60 tahun & $34,10 \%$ \\
\hline & c) $>61$ tahun & $45,20 \%$ \\
\hline \multirow[t]{6}{*}{ C. } & Pendidikan: & \\
\hline & a. SD & $17,70 \%$ \\
\hline & b. SMP & $28,50 \%$ \\
\hline & c. SMA & $20,20 \%$ \\
\hline & d. Perguruan Tinggi & $18,30 \%$ \\
\hline & e. Tidak Tamat & $15,30 \%$ \\
\hline \multirow[t]{4}{*}{ D. } & Mata pencaharian: & \\
\hline & a. Petani/peternak & $50,78 \%$ \\
\hline & b. PNS & $28,10 \%$ \\
\hline & c. Wiraswasta & $21,12 \%$ \\
\hline
\end{tabular}
pada informasi yang diberikan responden. Dari hasil penelitian memberikan gambaran terhadap karakteristik responden seperti pada Tabel 1.

Tabel 1. Karakteristik Responden 
Dari Tabel 1. diatas jika dilihat dari jenis kelamin menggambarkan bahwa peran perempuan dalam beternak sebesar 55\% dan lakilaki mencapai $45 \%$. Tingginya keterlibatan perempuan dalam beternak menunjukkan bahwa perempuan berperan penting dalam upaya mendukung ekonomi keluarga. Hal ini sesuai dengan pernyataan Suradisastra dan Lubis (2000), bahwa keterlibatan perempuan dalam kegiatan usaha peternakan tersebut merupakan upaya peningkatan keamanan ekonomi rumah tangga, termasuk pendapatan rumah tangga, dan peningkatan status perempuan dalam kegiatan sektoral. Umur responden menunjukkan sebanyak 45,20\% berumur lebih dari 61 tahun. Selanjutnya diikuti kelompok umur 41-60 tahun sebanyak $34,10 \%$ dan umur dibawah 40 tahun mencapai 20,70\%. Dari data tersebut dapat dikatakan bahwa peternak babi yang ada Kelurahan Prailiu dan Kambajawa Kabupaten Sumba Timur berada pada umur produktif dalam beternak babi. Hal ini mendukung laporan BPS (2016) bahwa usia produktif berkisar antara 1564 tahun.

Pendidikan responden bervariasi dari tidak tamat sampai pada tamat pendidikan. Hasil penelitian memperlihatkan bahwa pendidikan responden SD mencapai $17,70 \%$, SMP sebanyak $28,50 \%$, SMA terdapat $20,20 \%$, perguruan tinggi mencapai $18,30 \%$ dan yang tidak menamatkan pendidikan mencapai $15,30 \%$. Tingginya pendidikan responden dalam penelitian ini juga memberikan informasi bahwa peternak babi dilokasi penelitian tersebut memiliki pengetahuan baik dalam beternak.

Menurut Murtiyeni et al. (2005) melaporkan bahwa tingkat pendidikan peternak yang tinggi maka manajemen pemeliharaan ternak semakin baik karena peternak mudah mengadopsi inovasi dan perubahan pola pikir dalam memecahkan masalah lebih matang. Mata pencaharian petani/peternak yang diperoleh dalam penelitian ini mencapai 50,78\%.
Sebanyak 28,10\% berprofesi sebagai PNS yang juga sebagai peternak serta wiraswasta mencapai 21,12\% melakukan aktivitas beternak. Dengan demikian dapat dikatakan bahwa mata pencaharian masyarakat di lokasi penelitian merupakan bagian yang tidak terpisahkan dalam kehidupan sosial budaya.

\section{Struktur Populasi Ternak Babi}

Struktur populasi ternak babi perlu untuk diketahui untuk menentukan program yang akan dikembangkan. Disamping itu, bertujuan untuk mengetahui keseimbangan populasi ternak babi yang ada dilokasi penelitian sehingga tidak mempengaruhi struktur populasi yang ada. Berdasarkan data struktur populasi ternak babi yang diperoleh dapat dilihat pada tabel 2 .

Pada tabel 2, terlihat bahwa struktur populasi ternak babi di dominasi ternak betina jika dibandingkan dengan ternak jantan. Berdasarkan umur ternak babi di 2 kelurahan (Kambajawa dan Prailiu) tersebut secara berurutan ternak betina yang berumur 0-3 Bulan $(53,39 \%)$, umur $4-7$ bulan $(57,50 \%)$ dan umur di atas 8 bulan $(54,17 \%)$. Struktur populasi ternak jantan yang berumur 0-3 bulan sebanyak $46,61 \%$, umur 4-7 bulan mencapai $42,50 \%$ dan umur di atas 8 bulan terdapat $45,83 \%$. Dari hasil wawancana dengan responden ditemukan bahwa ternak jantan umumnya digunakan untuk kebutuhan adat isti adat. Selain itu, ternak babi jantan mempunyai nilai jual yang tinggi sehingga umumnya lebih banyak diperjualbelikan untuk memenuhi kebutuhan peternak. Berdasarkan pengamatan yang dilakukan ternyata ternak yang ada di lokasi penelitian belum ada sentuhan teknologi sehingga populasi yang ada berdasarkan sifat alami dan kemampuan adaptasi dari ternak itu sendiri. Sedangkan di NTT secara umum terdapat $85 \%$ ternak babi diternakkan secara tradisional (Johns et al. 2010).

Tabel 2. Data struktur populasi ternak babi

\begin{tabular}{llccc}
\hline \multirow{2}{*}{ Kelurahan } & Jenis & \multicolumn{3}{c}{ Berdasarkan Umur Ternak } \\
\cline { 3 - 5 } & Kelamin & Anak (0-3 bulan) & Muda (4-7 bulan) & Dewasa (>8 Bulan) \\
\hline \multirow{2}{*}{ Kambajawa } & Jantan & 17,29 & 18,75 & 19,79 \\
\multirow{2}{*}{ Prailiu } & Betina & 22,56 & 21,25 & 22,92 \\
& Jantan & 29,32 & 23,75 & 26,04 \\
& Betina & 30,83 & 36,25 & 31,25 \\
\hline \multicolumn{2}{r}{ Total } & 100,00 & 100,00 & 100,00 \\
\hline
\end{tabular}




\section{Performans Reproduksi Ternak Babi}

Usaha untuk meningkatkan produktivitas ternak babi di Sumba Timur, salah satunya ditentukan berdasarkan efisiensi reproduksi dari setiap ternak babi. Rata-rata data performans reproduksi yang diperoleh ditunjukan tabel 2 dibawah ini.

Tabel 2. Performans reproduksi ternak babi

\begin{tabular}{llll}
\hline $\begin{array}{l}\text { Rata-Rata } \\
\text { lama estrus }\end{array}$ & $\begin{array}{l}\text { Rata-rata } \\
\text { siklus estrus }\end{array}$ & $\begin{array}{l}\text { Rata-rata } \\
\text { liter size }\end{array}$ & $\begin{array}{l}\text { Rata-rata } \\
\text { mortalitas }\end{array}$ \\
\hline 3,25 hari & 20,45 hari & 9,75 ekor & $17,03 \%$ \\
\hline
\end{tabular}

Lama estrus yang diperoleh dalam penelitian ini yakni rata-rata 2,85 hari dan siklus estrus 20,45 hari. Hasil ini penelitian ini tergolong kategori normal yakni lama estrus 2-3 hari, siklus estrus 18-20 hari (Feradis, 2010). Data rataan liter size diperoleh dalam penelitian ini mencapai 9,75 ekor. Hasil ini lebih tinggi jika dibandingkan dengan penelitian (Aku et al. 2013) yakni rata-rata litter size 8,70 ekor. Namun, penelitian Sudiastra dan Budaarsa (2015) memperoleh liter size mencapai 10 ekor. Perbedaaan hasil liter size masih tergolong normal yakni berkisar 4-11 ekor (Usman et al., 2015). Menurut Tirajoh dan Usman (2011), menyatakan bahwa liter size setiap kelahiran untuk kelahiran pertama rata-rata mencapai 9 ekor, dan kelahiran ke-6 rata-rata 11 ekor serta jumlah kelahiran $65 \%$ dipengaruhi oleh faktor induk dan 35\% dipengaruhi oleh faktor lainnya.

Mortalitas yang ditemukan dalam penelitian ini mencapai 17,03\%. Sedangkan Aku et al., (2013), memperoleh mortalitas 19,69\%. Sedangkan Penelitian Usman et al., (2015), melaporkan tingkat mortalitas ternak babi sekitar $40-60 \%$. Mortalitas pada ternak babi dilokasi penelitian yakni anak tertindih induk karena sistem perkadangan yang tidak sesuai serta diare pada anak babi yang menyusui juga sebagai penyebab mortalitas. Dari hasil wawancana diperoleh informasi bahwa sumber pakan ternak yakni masyarakat mengandalkan dedak padi dan batang pisang maupun daun-daunan serta limbah sayuran kankung merupakan bahan pakan utama yang diberikan ternak babi sehingga sangat berpengaruh terhadap produksi susu, pertumbuhan ternak. Selain itu, pengetahuan peternak akan pencegahan penyakit (vaksinasi) masih rendah sehingga ternak dilokasi penelitian belum divaksin. Meskipun demikian data performans reproduksi ternak babi berbeda masing-masing peneliti hal ini disinyalir karena perbedaaan bangsa babi yang gunakan dalam penelitian, umur ternak, jenis perlakuan, musim, pakan yang diberikan, lingkungan dan genetik serta sistem peneliharaan dan pengalaman beternak.

\section{KESIMPULAN}

Berdasarkan hasil penelitian maka dapat disimpulkan bahwa struktur populasi ternak babi yang di Kelurahan Kambajawa dan Prailiu Kabupaten Sumba Timur didominasi ternak betina baik pada berbagai kriteria umur yakni umur 0-3 bulan (betina: 53,39\%; jantan 46,61\%), umur 4-7 bulan (betina: 57,50\%\%; jantan $42,50 \%$ ) dan umur diatas 8 bulan (betina: 54,17\%; jantan: $45,83 \%$ ). Sedangkan performans reproduksi dalam kategori baik yakni lama estrus 3,25 hari, siklus estrus 20,45 hari dan liter size $9,75 \%$ serta mortalitas mencapai $17,03 \%$.

Perlu dilakukan penelitian secara menyeluruh dan mendalam di seluruh Kecamatan di Kabupaten Sumba Timur untuk mengetahui struktur populasi dan performans reproduksi ternak babi.

\section{DAFTAR PUSTAKA}

Aku, A.S, T. Saili dan Amiruddin.2013. Sebaran, Struktur Populasi dan Kinerja Reproduksi Babi Lokal di Kecamatan Tinanggea Kabupaten Konawe Selatan. Agriplus, 23 (3): 118-192

Badan Pusat Statistik. 2014. Kabupaten Sumba Timur dalam Angka 2019. BPS Kabupaten Sumba Timur.

Badan Pusat Statistik. 2016. Profil Perempuan Indonesia 2011-2015. Kerjasama Kementerian Pemberdayaan Perempuan dan Perlindangan Anak dengan Badan Pusat Statistik. Kementerian Pemberdayaan Perempuan dan Perlindangan Anak (KPP dan PA)

Badan Pusat Statistik. 2019. Kabupaten Sumba Timur dalam Angka 2019. BPS Kabupaten Sumba Timur.

Sudiastra, I.W dan K. Budaarsa. 2015. Studi Ragam Eksterior Dan Karakteristik 
Reproduksi Babi Bali. Majalah Ilmiah Peternakan, 18 (3):100-105

Feradis. 2010. Bioteknologi Reproduksi pada Ternak. Alfabeta. Bandung.

Geisert, R.D. and R.A.M. Schmitt. 2002. Early Embryonic Survival in the Pig: Can it be Improved. J. Anim. Sci, 80 (1):54-85.

Johns C., Cargill C., Patrick I., Geong M., Johanis. 2010. Budidaya Ternak Babi Komersial Oleh Peternak Kecil di NTT Peluang Untuk Integrasi Pasar Yang Lebih Baik. Laporan Akhir ACIAR. Canberra (Australia): Australian Centre for International Agricultural Research.

Kaka, A. 2017. Performans reproduksi induk babi yang di pelihara secara intensif di Kelurahan Kambajawa Kabupaten Sumba Timur. Jurnal Ilmu-Ilmu Peternakan. 28 (1): 1-9

Murtiyeni, D. Priyantodan D. Yulistiani.2005. Karakteristik Peternak Domba atau Kambing dengan Pemeliharaan Di gembala atau Angon dan Hubungannya dengan Tingkat Adopsi Inovasi Teknologi.Seminar Nasional Teknologi Peternakan dan Veteriner. 2005

Sapanca, P.L.Y., I.W. Cipta dan I. M. Suryana. 2015. Peningkatan Manajemen Kelompok Ternak Babi di Kabupaten Bangli. Agrimeta 15(9): 1-69
Soewandi, B.D.P dan C. Talib. 2015. Pengembangan ternak Babi Lokal Indonesia. Wartazoa, 25(1):39-46

Sugiyono. 2013. Metode Penelitian Kuantitatif, Kualitatif dan R\&D. Bandung: CV. Alfabeta.

Suradisastra, K dan A.M. Lubis. 2000. Aspek Gender dalam Usaha Peternakan. Wartazoa, 10 (1): 13-19

Tirajoh, S. dan Usman, 2011. Litter Size" Suatu Faktor Penentu Keberhasilan Dalam Usaha Ternak Babi. Seminar Nasional. Pengkajian dan Diseminasi Inovasi Pertanian Mendukung Program Strategis Kementrian Pertanian. Cisarua, 9 - 11 Desember 2010.

Usman, B.M.W. Tiro, S.Tirajoh dan Bustami. 2015. Profil Kelompok Dan Kinerja Reproduksi Ternak Babi Lokal Pada Kelompok Tani Doligame Distrik Tiom, Kabupaten Lanny Jaya, Papua. Balai Pengkajian Teknologi Pertanian Papua dan Jambi.

Wea, R. 2007. Manajemen Pemeliharaan Ternak Babi Lokal di Kecamatan Kelapa Lima, Kota Kupang. Jurnal Partner Buletin Pertanian Terapan. Edisi Juli 2007. Politeknik Pertanian Negeri Kupang. 